\title{
Qualitative work overload and other risk factors related to hypertension risk among Indonesian Police Mobile Brigade (Brimob)
}

\author{
Riri Nusrad Kanam ${ }^{1}$, Bastaman Basuki ${ }^{1}$, Ginova Nainggolan ${ }^{2}$
}

\begin{abstract}
Abstrak
Anggota Brimob dapat mengalami hipertensi yang berkaitan dengan stresor pekerjaannya ataupun faktor risiko hipertensi lainnya. Oleh karena itu perlu diidentifikasi kaitan faktor stresor kerja dan faktor lainnya terhadap risiko hipertensi pada anggota Brimob. Subjek terdiri dari anggota Brimob yang sedang menjalani pemeriksaan kesehatan berkala selama bulan Juli-Oktober 2007. Subjek hipertensi adalah subjek dengan tekanan darah sistolik $140 \mathrm{mmHg}$ atau lebih, atau tekanan darah diastolik $90 \mathrm{mmHg}$ atau lebih, atau sedang minum obat antihipertensi. Subjek normal adalah subjek dengan tekanan darah sistolik kurang dari 120 mmHg dan diastolik kurang dari $80 \mathrm{mmHg}$ serta belum pernah menderita hipertensi. Di antara 336 anggota Brimob diperoleh 111 subjek hipertensi dan 79 subjek dengan tekanan darah normal yang berumur 21 hingga 51 tahun. Faktor-faktor yang berkaitan dengan hipertensi adalah kelebihan berat badan dan stresor beban kualitas berlebih. Faktor umur, faktor pekerjaan, gaya hidup, riwayat diabetes, riwayat hipertensi keluarga, dan stresor kerja lainnya tidak terbukti mempertinggi risiko hipertensi. Stresor beban kualitas sedang-berat dibandingkan dengan ringan meningkatkan risiko hipertensi dua kali lipat [risiko relatif suaian $(R R a)=2,0$; interval kepercayaan (CI) 95\% =0,97-4,14; $p=0,060]$. Dibandingkan subjek dengan berat badan normal, subjek dengan kelebihan berat badan memiliki risiko hipertensi 48\% lebih tinggi (RRa $=1,48 ; 95 \% C I=0,98-2,22)$, dan subjek obesitas memiliki risiko hipertensi dua kali lipat lebih (RRa $=2,21 ; 95 \% C I=1,51-3,14)$. Stresor beban kualitas berlebih dan kelebihan berat badan mempertinggi risiko hipertensi di antara anggota Brimob. Oleh karena itu perlu dilakukan pengendalian terhadap faktor-faktor tersebut. (Med J Indones 2008; 17: 188-96)
\end{abstract}

\begin{abstract}
Members of the Police Mobile Brigade (Brimob) can suffer from hypertension which is related to work stressors and other risk factors. This study aimed to identify the relationship between work stressors and other hypertensive risk factors. The subjects of this crosssectional study were members of the Brimob undergoing their periodic medical check-up during July-October 2007. A subject was hypertensive if systolic blood pressure (SBP) was $140 \mathrm{mmHg}$ or higher, or diastolic (DBD) $90 \mathrm{mmHg}$, or higher or taking antihypertensive drugs. Normal subjects were those who had SBP less than $120 \mathrm{mmHg}$ and DBP less than $80 \mathrm{mmHg}$, and have never been diagnosed with hypertension. A number of 336 Brimobs aged 21 to 51 years participated in this study, 111 had high blood pressure and 79 had normal blood pressure. Hypertension was found to be related to excessive body weight and qualitative work overload. Age, work, lifestyle, history of diabetes, hypertension in the family, and other work stressors were not found to increase the risk of hypertension. Medium to high level qualitative work overload had a two-fold risk for hypertension [relative risk adjusted $(R R a)=2.00 ; 95 \%$ confidence interval (CI) $=$ 0.97-4.14; $p=0.060]$. Overweight subjects had 48\% increased risk to hypertension (RRa $=1.48 ; 95 \%$ CI $=0.98-2.22)$. Obese subjects had a two-fold risk of being hypertensive ( $R R a=2.21 ; 95 \% C I=1.51-3.14)$. Qualitative work overload and obesity increased the risk of hypertension. These risk factors should therefore be controlled. (Med J Indones 2008; 17: 188-96)
\end{abstract}

Keywords: hypertension, qualitative work overload, overweight, obese

The police force, specifically the members of the Indonesian Police Force (Kepolisian Republik Indonesia or POLRI), are officers concerned mainly with law

\footnotetext{
${ }^{1}$ Department of Community Medicine, Faculty of Medicine, University of Indonesia, Jakarta, Indonesia

2 Department of Internal Medicine, Faculty of Medicine, University of Indonesia/Dr. Cipto Mangunkusumo Hospital, Jakarta, Indonesia
}

and order, keeping the peace in the community, enforcing the law, detect and prevent crime. ${ }^{1}$ One of the units in the Polri is the Mobile Brigade (Brimob) that provides technical support in tactical operations. The Brimob is present in every high intensity crisis, mass riots, or disasters that needs emergency aid, which can occur in remote inaccessible places.

The excellent health and superior physical fitness of police officers or members of the Brimob are the 
main assests in performing their duties. Any health problem, such as hypertension, can endanger not only the individual but other members of his unit, or the community they are supposed to protect.

The prevalence of cardiovascular diseases in the police force is twice or more than in the general population. A study on male law enforcement officers in the United States reported that when compared to men of the same age and income bracket in the general population, the police officers had a higher prevelance of hypertension. ${ }^{2}$

Working as a police officer or the Brimob means working in a stressful environment. The stressors include, irregular working hours, shift work, tour of duty to areas of conflict which are usually far from home and family for long periods of time, confronting criminals and dangerous situations, always in a state of alertness, even when off duty, highly hierarchical system of rank, and stressor of carreer development. ${ }^{3}$

Attention is currently centered at the workplace, where studies focus on potential sources of stress that can lead to hypertension in the workers. ${ }^{4,5}$ Qualitative overload is one of the work-related stressors that occurs when there is a discrepancy between technical capability and knowledge compared to the demands of the work at hand. ${ }^{8}$ The duties of members of the Brimob can be a source of qualitative overload stress, for example defusing explosives needs technical capabilities, speed, and accuracy, or crowd handling needs an ability to control emotions and patience so as not to act above the law. There it is important to identify the relationship between these factors on hypertension among the members of the Brimob. It is hoped that this will help to prevent or control hypertension in an effort to maintain health and physical fitness of the police, and specifically the members of the Brimob.

This study aimed to identify overload of qualitative work stressor and other risk factors related to hypertension risk among police mobile brigade (Brimob).

\section{METHODS}

The subjects for this cross-sectional study were Brimob members undergoing their periodic medical check-up between the months of July and October 2007. They were chosen by consecutive sampling and must have had a tour of duty in a conflict area. The study was carried out at one of the Brimob headquarters.
Data on age, marital status, level of education, blood pressure, body height and weight, work unit, length of employment, rank, post tour of duty, exercise, smoking, coffee, diabetes mellitus, family history of hypertension were recorded on a form especially constructed for this study.

The subject had to take off their uniforms, empty out their pockets and remove their shoes during weighting sessions. The uniforms of the Brimob are full of attributes made of metal that can add to their body weight. They were also shoeless for body height measurements.

Blood pressure was measured according to the JNC 7 standard using a mercury sphygmomanometer (Nova Riester) that is regularly calibrated and a stethoscope (Riester). The readings were done by paramedical staff. The subject was classified as hypertensive if systolic blood pressure was $140 \mathrm{mmHg}$ or more, or a diastolic pressure of $90 \mathrm{mmHg}$ or more, or is currently on antihypertensive drugs. Blood pressure was classified as normal if the systolic blood pressure was 119 $\mathrm{mmHg}$ or less, and the diastolic blood pressure was 79 $\mathrm{mmHg}$ or less, or have never taken been diagnosed as hypertensive.

Work unit is the current unit where the subject is stationed (1/Gegana Unit; 2/Pelopor Unit; 3/Pelopor Unit). Post tour of duty is the last tour of duty before the medical check-up.

Exercise is classified as light, moderate and heavy based on the intensity, frequency, and duration of one exercise session.

Length of employment was calculated from the time the subject was accepted as a police officer until the present.

Work stressor was diagnosed using a diagnostic questionnaire, Kuesioner Diagnostik Stress Kerja. ${ }^{6}$ The subject had to fill his answers on the questionnaire made up of 30 questions on 6 types of work-related stressors. They had to answer from a scale of $1-7$, the condition that fits the questions on stress.

The rating of $1-7$ is as follows: $1=$ if the condition in the question never causes stress; 2 = if the condition in the question almost never causes stress; $3=$ if the condition in the question seldom causes stress; $4=$ if the condition in the question sometimes causes stress; $5=$ if the condition in the question often causes stress; 
$6=$ if the condition in the question very often causes stress; $7=$ if the condition in the question always causes stress.

The 6 types of work-related stressors evaluated were: role ambiguity, role conflict, quantitative overload, qualitative overload, carreer development, and personal responsibility. The accumulated score was classified as low if less than 10 , and moderate to high if more than 10.

Relative risk (RR) was used since the prevalence of hypertension among Brimob members was more than $20 \%$, with a Confidence Interval of $95 \%$ based on the result of Cox regression analysis hasil analisis with time constant [Barros]. ${ }^{7}$ STATA version 9 was used for statistical analysis.

Ethical approval was obtained from the Research Ethical Commission of FKUI. The study was undertaken after approval was granted by the Chief of the Brimob (Kakor Brimob). The subjects-to-be were first briefed on the aim and purpose of the study, and those that agreed to become subjects were given the questionnaires to be filled in, guided by investigator aided by several paramedical staff.

\section{RESULTS}

There were 340 members of the Brimob eligible as subjects-to-be, but 4 did not fill in the questionnaire, leaving 336 as subjects. Out of 336, 146 was excluded from analysis because they were either diagnosed as prehypertensive or were normotensive but have had a history of hypertension. The sample included in the final analysis were 190, which consisted of 111 with normal blood pressure and 79 with hypertension (stages $1 \& 2$ ). None of the subjects are on antihypertensives.

Table 1. Some demographic and work characteristics and the risk of hypertension

\begin{tabular}{|c|c|c|c|c|c|c|c|}
\hline & \multicolumn{2}{|c|}{$\begin{array}{c}\text { Normal } \\
(\mathrm{N}=111) \\
\end{array}$} & \multicolumn{2}{|c|}{$\begin{array}{c}\text { Hypertension } \\
(\mathrm{N}=79)\end{array}$} & \multirow{2}{*}{$\begin{array}{c}\text { Crude } \\
\text { Relative } \\
\text { Risk }\end{array}$} & \multirow{2}{*}{$\begin{array}{c}95 \% \\
\text { Confidence } \\
\text { Interval }\end{array}$} & \multirow{2}{*}{$\mathrm{P}$} \\
\hline & $\mathrm{n}$ & $\%$ & $\mathrm{n}$ & $\%$ & & & \\
\hline \multicolumn{8}{|l|}{ Age category } \\
\hline $21-29$ years & 78 & 61.4 & 49 & 38.6 & 1,00 & Reference & \\
\hline $30-51$ years & 33 & 52.4 & 30 & 47.6 & 1.23 & $0.78-1.94$ & 0.364 \\
\hline \multicolumn{8}{|l|}{$\mathrm{N} / \mathrm{a}=$ Not applicable } \\
\hline Unmarried & 28 & 60.9 & 18 & 39.1 & 1.00 & Reference & \\
\hline Married & 82 & 57.3 & 61 & 42.7 & 1.09 & $0.64-1.84$ & 0.748 \\
\hline Divorced/widowed & 1 & 100 & 0 & 0 & $\mathrm{~N} / \mathrm{a}$ & - & - \\
\hline \multicolumn{8}{|l|}{ Level of education } \\
\hline Senior high school & 107 & 57.8 & 78 & 42.2 & 1.00 & Reference & \\
\hline University & 4 & 80 & 1 & 20 & 0.7 & $0.7-3.41$ & 0.459 \\
\hline \multicolumn{8}{|l|}{ Work unit } \\
\hline Unit 1/Gegana & 0 & 0 & 3 & 100 & 1.00 & Reference & \\
\hline Unit 2/Pelopor & 41 & 67.2 & 20 & 32.8 & 0.33 & $0.10-1.10$ & 0.072 \\
\hline Unit 3/Pelopor & 70 & 55.6 & 56 & 44.4 & 0.44 & $0.14-1.42$ & 0.171 \\
\hline \multicolumn{8}{|l|}{ Rank } \\
\hline Bripda & 96 & 58.9 & 67 & 41.1 & 1.00 & Reference & \\
\hline Briptu-Brigadir & 10 & 50.0 & 10 & 50.0 & 1.22 & $0.63-2.36$ & 0.563 \\
\hline Bripka or above & 5 & 71.4 & 2 & 28.6 & 0.70 & $0.17-2.84$ & 0.612 \\
\hline \multicolumn{8}{|l|}{ Length of employment } \\
\hline $1-5$ years & 14 & 73.7 & 5 & 26.3 & 1.00 & Reference & \\
\hline $5-10$ years & 84 & 56.8 & 64 & 43.2 & 1.64 & $0.66-4.08$ & 0.285 \\
\hline $10-31$ years & 13 & 56.5 & 10 & 43.5 & 1.65 & $0.56-4.83$ & 0.359 \\
\hline \multicolumn{8}{|l|}{ Post tour of duty } \\
\hline 5-156 weeks & 36 & 62.1 & 22 & 37.9 & 1.00 & Reference & \\
\hline $1-4$ weeks & 11 & 91.7 & 1 & 8.3 & 0.22 & $0.03-1.63$ & 0.138 \\
\hline 1 day - 1 week & 46 & 49.5 & 47 & 50.5 & 1.33 & $0.80-2.21$ & 0.267 \\
\hline
\end{tabular}

$\mathrm{N} / \mathrm{a}=$ Not applicable 
Table 1 shows that the subjects with hypertension and those with normal blood pressure were equally distributed in terms of age, marital status, level of education, rank, and length of employment.

When compared to the subject that was more than 4 weeks post tour of duty, the subject that have only been home 1 day -1 week had a higher blood pressure, and the subject that have been home 1 week -1 month had a lower blood. In the work units, the $2 /$ Pelopor unit and the 3/Pelopor unit have a lower risk of being hypertensive.

In Table 2, it can be seen that the subjects with hypertension and those with normal blood pressure were equally distributed in terms of exercise, smoking, coffee, history of diabetes mellitus, and family history of hypertension.

Table 3 shows that subjects with hypertension and subjects with normal blood pressure were normally distributed (no significant difference) in terms of work-related stress such as role ambiguity, role conflict, quantitative work overload, carreer development, and personal responsibility. There were more subjects with hypertension with moderate to high quanlitative work overload than those with low qualitative work overload.

Table 2. Exercise, smoking, coffee, diabetes mellitus, and family history of hypertension and the risk of hypertension

\begin{tabular}{|c|c|c|c|c|c|c|c|}
\hline & \multicolumn{2}{|c|}{$\begin{array}{l}\text { Normal } \\
(\mathrm{N}=111)\end{array}$} & \multicolumn{2}{|c|}{$\begin{array}{l}\text { Hypertension } \\
\qquad(\mathrm{N}=79)\end{array}$} & \multirow{2}{*}{$\begin{array}{c}\text { Crude } \\
\text { Relative } \\
\text { Risk }\end{array}$} & \multirow{2}{*}{$\begin{array}{c}95 \% \\
\text { Confidence } \\
\text { Interval }\end{array}$} & \multirow{2}{*}{$\mathrm{P}$} \\
\hline & $\mathrm{n}$ & $\%$ & $\mathrm{n}$ & $\%$ & & & \\
\hline \multicolumn{8}{|l|}{ Exercise } \\
\hline Light & 32 & 57.1 & 24 & 42.9 & 1.00 & Reference & \\
\hline Moderate & 35 & 63.6 & 20 & 36.4 & 0.85 & $0.47-1.54$ & 0.587 \\
\hline Heavy & 44 & 55.7 & 35 & 44.3 & 1.03 & $0.62-1.74$ & 0.900 \\
\hline \multicolumn{8}{|l|}{ Smoking } \\
\hline Never & 21 & 50.0 & 21 & 50.0 & 1.00 & Reference & \\
\hline Past & 24 & 50.0 & 24 & 50.0 & 1.00 & $0.56-1.80$ & 1.000 \\
\hline Current & 66 & 66.0 & 34 & 34.0 & 0.68 & $0.39-171$ & 0.165 \\
\hline \multicolumn{8}{|l|}{ Coffee/day } \\
\hline None & 56 & 58.3 & 40 & 41.7 & 1.00 & Reference & \\
\hline Less than 1 cup/day & 45 & 58.4 & 32 & 41.6 & 1.00 & $0.63-1.59$ & 0.991 \\
\hline 1/more cups/day & 10 & 58.8 & 7 & 41.2 & 0.99 & $0.44-2.21$ & 0.997 \\
\hline \multicolumn{8}{|l|}{ Diabetes mellitus } \\
\hline Never & 98 & 57.0 & 74 & 43.0 & 1.00 & Reference & \\
\hline Unknown & 13 & 72.2 & 5 & 27.8 & 0.86 & $0.64-1.17$ & 0.344 \\
\hline \multicolumn{8}{|c|}{ Family history of hypertension } \\
\hline None & 87 & 60.0 & 58 & 40.0 & 1.00 & Reference & \\
\hline Yes & 9 & 42.9 & 12 & 57.1 & 1.43 & $0.77-2.66$ & 0.261 \\
\hline Unknown & 15 & 62.5 & 9 & 37.5 & 0.94 & $0.46-1.89$ & 0.857 \\
\hline
\end{tabular}


Table 3. Work-related stress and the risk of hypertension

\begin{tabular}{|c|c|c|c|c|c|c|c|}
\hline & \multicolumn{2}{|c|}{$\begin{array}{c}\text { Normal } \\
(\mathrm{N}=111)\end{array}$} & \multicolumn{2}{|c|}{$\begin{array}{c}\text { Hypertension } \\
(\mathrm{N}=79)\end{array}$} & \multirow{2}{*}{$\begin{array}{c}\text { Crude } \\
\text { Relative } \\
\text { Risk }\end{array}$} & \multirow{2}{*}{$\begin{array}{c}95 \% \\
\text { Confidence } \\
\text { Interval }\end{array}$} & \multirow[t]{2}{*}{$\mathrm{P}$} \\
\hline & $\mathrm{n}$ & $\%$ & $\mathrm{n}$ & $\%$ & & & \\
\hline \multicolumn{8}{|l|}{ Role ambiguity } \\
\hline Slight & 50 & 59.5 & 34 & 40.5 & 1.00 & Reference & \\
\hline Moderate - high & 61 & 57.6 & 45 & 42.4 & 1.05 & $0.67-1.64$ & 0.834 \\
\hline \multicolumn{8}{|l|}{ Role conflict } \\
\hline Slight & 54 & 55.1 & 44 & 44.9 & 1.00 & Reference & \\
\hline Moderate - high & 57 & 62.0 & 35 & 38.0 & 0.85 & $0.54-1.32$ & 0.645 \\
\hline \multicolumn{8}{|c|}{ Quantitative overload } \\
\hline Slight & 43 & 51.8 & 40 & 48.2 & 1.00 & Reference & \\
\hline Moderate - high & 68 & 63.6 & 39 & 36.4 & 0.76 & $0.49-1.18$ & 0.215 \\
\hline \multicolumn{8}{|l|}{ Career development } \\
\hline Low & 53 & 55.2 & 43 & 44.8 & 1.00 & Reference & \\
\hline Moderate - high & 58 & 61.7 & 36 & 38.3 & 0.86 & $0.55-1.33$ & 0.488 \\
\hline \multicolumn{8}{|c|}{ Personal responsibility } \\
\hline Low & 22 & 56.4 & 17 & 43.6 & 1.00 & Reference & \\
\hline Moderate - high & 89 & 58.9 & 62 & 41.0 & 0.94 & $0.55-1.61$ & 0.827 \\
\hline
\end{tabular}

The final model (Table 4) shows that the risk of hypertension is related to BMI, and qualitative work overload. The higher the body weight (higher BMI) the higher the risk of hypertension.

When compared to subjects with normal body weights, those that are overweight had a $48 \%$ high risk $(p=0.059)$ of being hypertensive, where as obese individuals had a 2.2 fold risk of hypertension $(p=0.000)$.

Furthermore, in term of qualitative work overload, those who had moderate-high than low qualitative work had two-fold increase risk to be hypertension $(p=0.060)$.

Table 4. The relationship between body mass index, qualitative work overload and the risk of hypertension

\begin{tabular}{|c|c|c|c|c|c|c|c|}
\hline & \multicolumn{2}{|c|}{$\begin{array}{c}\text { Normal } \\
(\mathrm{N}=111)\end{array}$} & \multicolumn{2}{|c|}{$\begin{array}{c}\text { Hypertension } \\
(\mathrm{N}=79)\end{array}$} & \multirow{2}{*}{$\begin{array}{c}\text { Adjusted } \\
\text { Relative } \\
\text { Risk* }\end{array}$} & \multirow{2}{*}{$\begin{array}{c}95 \% \\
\text { Confidence } \\
\text { Interval } \\
\end{array}$} & \multirow[t]{2}{*}{$\mathrm{P}$} \\
\hline & $\mathrm{n}$ & $\%$ & $\mathrm{n}$ & $\%$ & & & \\
\hline \multicolumn{8}{|l|}{ Body weight (BMI) } \\
\hline Normal & 79 & 66.9 & 39 & 33.0 & 1.00 & Reference & \\
\hline Overweight & 28 & 54.5 & 20 & 45.6 & 1.48 & $0.98-2.22$ & 0.059 \\
\hline Obese & 8 & 28.6 & 20 & 71.4 & 2.21 & $1.51-3.14$ & 0.000 \\
\hline \multicolumn{8}{|c|}{ Qualitative work overload } \\
\hline Low & 19 & 76.0 & 6 & 24.0 & 1.00 & Reference & \\
\hline Moderate - high & 92 & 55.8 & 73 & 44.2 & 2.00 & $0.97-4.14$ & 0.060 \\
\hline
\end{tabular}

* Relative risk is adjusted between the two variables in this table 


\section{DISCUSSION}

This study has several limitations originating from the choice of population, the selection of subjects, or from the information obtained.

The study was directed only at a segment of the Brimob, those undertaking their periodic medical check-up. These officers are designated for further training and promotion and units that have just returned from their tour of duty. Therefore, the sample obtained did not represent the entire Brimob in Indonesia.

A source of information bias is the technique employed in the interviews. Furthermore, hypertension in this study was made based on cross-sectional data which might not conform to standards in the clinic, and the possibility of secondary hypertension was not explored.

This study is probably the first to investigate the relationship between work-related stressor and hypertension in the Brimob, which is of course an advantage. In addition, total number 190 of sample subjects is much more is much larger than the minimal number of sample needed. This increased the strength of the study and allowed further analysis of other risk factors of hypertension.

There was 79 (23.5\%) officers with hypertension. This figure is almost similar with young adult population working at the Israeli Department of Defense, where the prevalence of hypertension was about $18.9 \%$. The prevalence of hypertension among young adult population of the United States was 33\% in young adult Afro-Americans and $25 \%$ in the young adult Caucasians. $^{8}$

In the final model, subjects with moderate to high qualitative work overload had a higher risk of hypertension $(\mathrm{RR}=2.21 ; \mathrm{p}=0.060)$. Out of 190 subjects, 165 subjects had moderate to high qualitative work overload. This is more than $80 \%$, which is a relatively high number. For that reason, even if the results of this study are not able to show a strong relationship between work-related stress and the risk of hypertension, attention must be paid to high qualitative work overload in order to maintain a healthy Brimob.

Many studies have confirmed the relationship between work-related stress and the risk of hypertension in employees. A study on employees of an office in Jakarta in 2004 concluded that moderate to high qualitative work overload increased the risk of hypertension by 7-fold. ${ }^{9}$ Other studies on various professions in Japan and on law enforcement officers, including policemen, in the United States verify the relationship between work-related stress and the increased prevalence of hypertension..$^{2,10}$

When compared to the results of Krisnawati on office workers, where moderate to high qualitative work overload had a 7-fold increase on the risk of hypertension, ${ }^{9}$ the members of Brimob seeme to have a better coping mechanism. The risk of hypertension was only 2-fold in moderate to high qualitative overload in the Brimob.

Nevertheless efforts in stress management needs to be increased in the Brimob work environment. Various stress management methods have been developed for police officers, such as the one implemented in Florida, USA called the HeartMath Self-Management Skill Program. This is a program designed to train members of the police force to control physiological and psychological stresses encountered. ${ }^{11}$ Stress management in the workplace has proven to be effective in improving cardiovascular disregulation caused by stress reaction, by lowering systolic arterial blood pressure and therefore will benefit hypertension prevention programs. ${ }^{12}$

The first step in stress management training is recognizing the reactions and symptoms of stress, followed by training to increase personal skills in controlling the stress. Controlling stress must also be carried out at the level of the organization of the workplace. This will help to reduce stress originating from rules and regulation at the workplace. This can be further supplemented by help and counseling programs aimed at the employees experiencing stress, such as treatment and rehabilitation.

Further improvement on programs, such as refresher courses and technical training, along with courses to broaden knowledge of the Brimob members, need to be carried out. These programs will enhance personal development, and thus promote ability as well as selfconfidence in handling duties among the community.

This study found that the risk of hypertension is higher among the overweight or obese compare to subjects with nomal body weight. This coincides with finding of other studies, where the risk of hypertension increases with excess weight and obesity, especially in the young adult population. ${ }^{9,13-15}$ 
In this study, out of the 190 subjects, 44 were categorized as overweight and 28 were obese. Therefore further investigations should be done to evaluate the distribution of body fat by measuring the waist circumference. As we know, the members of Brimob are highly trained individuals that have undergone intense physical training, so we need to assess whether the high Body Mass Index (BMI) is due to fat deposition or due to large muscle mass resulting from physical training. In addition, further investigations should be done to find the causes of overweight and obesity among the Brimob, whether it is related to changes in living styles, such as an unbalanced diet.

Several papers and studies have confirmed that the prevalence of hypertension increased with age, more than half of the population between the ages of 60-69 years and $75 \%$ of those aged 70 years are hypertensive. The Framingham Heart Study reported on the risk of hypertension and age; the risk of hypertension in men and women aged 55 or 65 years is about $90 \%{ }^{16}$ However in this study, age was not found to be a risk factor for hypertension. This was probably dure to the limited number of sample and the age of the subjects, which ranged between $21-51$ years. Therefore this study could not prove that increasing age increases the risk of hypertension.

This study did not find marital status to be a risk factor of hypertension. Out of 190 subjects, 46 were not married, 143 were married and only 1 was divorced. Statistical analysis could not be done since there was only 1 subject in the divorced group. This group could not be grouped together with the unmarried group because the conditions between the groups was dissimilar. Other studies have stated that the loss of a partner is a one of the major stressors in a persons's life. A study in the Cijeruk area of the Bogor district found that subjects that were either divorced or widowed had a higher risk for hypertension when compared to those married or not married. ${ }^{13}$

A larger sample may be needed to establish the relationship between marital state and hypertension, a larger sample will ensure that there is enough subject in each group.

Analysis of job characteristics, such as the work unit, showed that subjects belonging to Units 2 and 3 (Pelopor) had a lesser risk of being hypertensive compared to those in Unit 1 (Gegana). This is consistent with the more dangerous duties of the Gegana Unit, which is a special operations unit responsible for handling high intensity states of emergency. One of their main duties is to act as bomb squad. The job and the possibility of death in the line of duty, along with the pressure to decide and act quickly can be categorized as qualitative workload stress. For this reason the work unit can be included as a risk factor for hypertensionin the Brimob.

Nevertheless further study with sufficient sample size is needed to represent each work unit. The sample for the Gegana Unit was very small compared to the samples in the other work units.

Rank was not found to be a risk factor for hypertension among members of the Brimob. This findings is not the same as the findings of several prior studies that found an association between the level of work and the risk of hypertension.

A study of 6,587 workers of various levels in Japan found that lower level workers had a higher risk of hypertension than workers from the managerial level, and that blue collar workers also had a higher risk of hypertension compared to the white collar workers. ${ }^{10}$

A different finding was shown in survey III of the MONICA population, with a sample of 1,571 subjects. The managerial level was shown to have a higher risk of hypertension than the lower level workers. ${ }^{17}$

The length of employment as a police officer was not found to be a risk factor for hypertension among the members of Brimob. This result differs from prior results, where longer length of employment was found to increase the risk of hypertension among the sample studied. ${ }^{9,18}$

The length of employment in this study was relatively the same and not equally dispersed between the groups because the members of the unit were of the same age group, rank, and length of employment.

From the crude relative risk it can be seen that the subjects 1 day to 1 week post tour of duty had higher blood pressure compared with subjects with more than 4 weeks post tour of duty, while subjects with 1 week to 1 month post tour of duty had lower blood pressure. This can be the result of work-related stress encountered during the tour of duty causing an increase in epinephrine, which may still be high in the first week back from duty and decreased after the break and 1 month after post duty. ${ }^{21}$ 
All 190 of the sample routinely exercise, either light or heavy exercise. Analysis of the data showed that exercise was not associated with the risk of hypertension in Brimob. This result differs from other studies where exercise can reduce the risk of hypertension. ${ }^{19,20}$ The reason for our result was probable due all subjects routinely exercise.

The habit of smoking was not found to influence the risk of hypertension among the subject. In previous studies, smoking was shown to be a risk factor for cardiovascular diseases, specifically coronary heart diseases and not a direct risk for hypertension. Smoking and hypertension together will increase the risk of coronary heart diseases. ${ }^{16,21}$

The habit of drinking coffee was also not found to be influence the risk of hypertension. This result agrees with prior studies, where individuals that are not in the habit of drinking coffee will increase blood pressure caused by caffeine. But the body will quickly tolerate this effect in three days of coffee drinking, and caffeine will not cause a presistent increase in blood pressure. ${ }^{21}$

Past diabetics was not found to be at risk for hypertension. This was probably due to the very small sample, since no subject was found to have suffered from diabetes, and statistical analysis cannot be carried out.

A family history of hypertension was not found to be a significant risk factor for hypertension in this study. This differs from previous studies that found individuals with parents suffering from hypertension will have a two fold risk of being hypertensive when compared with individuals with no hypertension in their families. ${ }^{16,21}$ The small sample could be the reason why this study did not find a family history of hypertension increase the risk of hypertension.

From bivariate analysis it can be seen that subjects with moderate to high quantitative overload seem to be at lesser risk of hypertension when compared to subjects with slight quantitative overload. This result differs from a study by Krisnawati on employees of a certain office in Jakarta. The study found that moderate to high quantitative overload increased the risk of hypertension.

The decrease in the risk of hypertension caused by an increase in quantitative overload could be due to the sample population of this study. Quantitative overload may be consistent with physical load and may therefore reproduce the effects of heavy physical activity which can reduce the risk of hypertension.

Other work-related stressors, such as role ambiguity, role conflict, carreer development, and personal responsibility seemed to have no association with the risk of hypertension in the subjects of this study. A member of Brimob has duties and roles defined by rules and regulations. Carreer development is also wellregulated with periodic advancement in rank, as other members of the police force or civil servants. Therefore, members of the Brimob generally understands the duties and responsibilities that goes with the job, and carreer development is not an issue that has to be personally attended.

It can be concluded that qualitative work stress and overweight and obesity are factors that increased the risk of hypertension among members of Brimob. Therefore, these factors, qualitative work overload management and control of body weight, should be included in programs for maintaining health of Brimob members. Further studies, to establish the relationship between work-related stress and the risk of hypertension among Brimob members, should also be undertaken by using questionnaires that are specifically tailored to the duties of the Brimob.

\section{Acknowledgments}

The authors wish to thank all subjects who cooperatively participated in this study. We also would like to express our gratitude to Dr. Glenn Kaunang who facilitated this study.

\section{REFERENCES}

1. Suparlan P. Polisi dan fungsinya dalam masyarakat. In: Suparlan P, editor. Bunga rampai ilmu kepolisian Indonesia. Jakarta: Yayasan Pengembangan Kajian Ilmu Kepolisian; 2004.

2. Franke WD, Ramey SL, Shelley MC. Relationship between cardiovascular disease morbidity, risk factors, and stress in a law enforcement cohort. J Occup Environ Med. 2002;44:1182-89.

3. International hazard datasheets on occupation. Police/Law Enforcement Officer. International Occupational Safety and Health Information Center. [Cited 2006 Dec 20]. Available from:http://www.ilo.org/public/english/protection/safework/ cis/products/hdo/htm/offer_police. 
4. Work Stress Network. Definition and formulation of work strain. [Cited 2007 April 10]. Available from: http://www. workhealth.org/strain/jsdef.html.

5. Fine LJ, Rosenstock L. Cardiovascular disorders. In: Rosenstock L, Cullen MR, Brodkin CA, Redlich CA, editors. Textbook of clinical occupational and environmental medicine. 2nd Ed. Philadelphia: Elsevier Saunders; 2005. p.549-64.

6. Isfandari S. Penelitian instrumen survei diagnosa stress dan stress strain. Jakarta: Badan Penelitian dan Pengembangan Departemen Kesehatan RI; 1992.

7. Barros AJD, Hirakata VN. Alternative for logistic regression in cross-sectional studies: an empirical comparison of models that directly estimates the prevalence ratio. BMC Medical Research Methodology. Oct. 2003; 3 (21). Downloaded from: http://www.biomedcentral.com/14712288/3/21

8. Perry WCB, Campbell KL, Mutaugh KH, Falkner B, Gidding $\mathrm{S}$. The assosiation between hypertension and other cardiovaskular risk faktor in young adult African Americans. J Clin hypertens. 2002;4:17-22.

9. Krisnawati F, Basuki B, Nainggolan G. Work stressors and other risk factors related to the risk of hypertension among selected employees in Jakarta. Med J Indones. 2006;15:17784.

10. Tsutsumi A, Kayaba K, Tsutsumi K, Igarashi M. Association between work strain and prevalence of hypertension: a cross sectional analysis in Japanese working population with a wide range of occupation: the Jichi Medical School cohort study. J Occup Environ Med. 2001;58:367-73.

11. Impact of the HeartMath Self-Management skill program on physiological and psychological stress in police Officers. Discussion. http://www.heartMath.org/research/researchpapers/police/index.html.
12. Lucini D, Riva S, Pizzinelli P, Pagani M. Stress management at the worksite. Reversal of symptoms profile and cardiovascular dysregulation. Hypertension. 2007; 49: 291-7.

13. Basuki B, Setianto B. Age, body posture, daily working load, past antihypertensive drugs and risk of hypertension: A rural Indonesian study. Med J Indones. 2001;10:29-33.

14. Bramlage P, Pittrow D, Witchen HU, Kirch W, Boehler S, Lehnert $\mathrm{H}$, et al. Hypertension in overweight and obese primary care patients is highly prevalent and poorly controlled. Am J Hypertens. 2004; 17:904-10.

15. Pinzon R. Indeks massa tubuh sebagai risiko hypertension pada usia muda. Cermin Dunia Kedokteran. 1999; 123:911.

16. The Seventh Report of the Joint National Committee on Prevention, Detection, Evaluation and Treatment of High Blood Pressure. Complete report. USA: U.S. Department of Health and Human Services. The Institutes; 2003.

17. Sutedjo. Profil hipertension pada populasi MONICA 2000 , (Survey III). Divisi penelitian dan pengembangan pusat, RS Jantung Harapan Kita. dikutip pada 20/12/2006.dari http:// www.pjnhk.go.id/pusdalit/2006/05/22/profil-hypertensionpada-populasi-monica

18. Undari J. Prevalensi hypertension terkait dengan stres kerja dan faktor lain yang berhubungan pada karyawan rumah sakit X di Jakarta. (Tesis). Jakarta: Univ Indones; 2006.

19. Munandar AS. Stress dan keselamatan kerja, psikologi industri dan organisasi. Jakarta: UI Press; 2001.

20. Nakanishi N, Suzuki K. Daily life activity and the risk of developing hypertension in middle-aged Japanese men. Arch Intern Med. 2005;165:214-20.

21. Kaplan NM. Primary hypertension: Pathogenesis. In: Clinical hypertension. Sixth edition. Baltimore: Williams \& Wilkins; 2004. p 47-98. 